\title{
The Community Empowerment Strategy in Protected Forest Management through Community-Based Ecotourism Development in Kalibiru Village, Kulon Progo Regency
}

\author{
Wiyono $^{1}$, Rochmad Hidayat ${ }^{2}$, Silvi Nur Oktalina ${ }^{3}$ \\ Department of Bioresources Technology and Veterinary, Vocational School, Gadjah Mada University \\ Received: 9 December 2019; Revised: 9 January 2020; Accepted: 20 January 2020
}

\begin{abstract}
The forest management strategies in Indonesia are starting to change from state-based forest management to community-based forest management. The changing of forest management strategies can be seen in the implementation of the Social Forestry Program at Kulon Progo Regency. This study aimed to know the strategies and benefits of community empowerment in managing protected forests by ecotourism. This research conducted on July - October 2019 in The Community Forest Farmer Group of Mandiri at Kalibiru Village, Kulon Progo Regency. Data collection was done by several methods including (1) Indepth interview to the head of forest farmer group; (2) Focus group discussion with the committee of forest farmer group; (3) Field observation; and (4) Secondary data review. The data analyzed by descriptive method. The results of the study indicated that the forms of community empowerment strategies in protected forest management carried out by KTHKm Mandiri included: (1) Institutional management strategies through strong institutional governance of farmer groups; (2) Forest area management strategies through the application of the concepts of resources-based management, ecosystem-based management, and landscape-based management; (3) Forest business management strategy through the application of the concept of community-based ecotourism. The existence of Kalibiru Ecotourism has been proven to provide economic benefits to members of the group, as well as residents of the Kalibiru and surrounding communities, in the form of (1) profit sharing; (2) employment; (3) new business opportunities; and (4) social funding assistance. The existence of Kalibiru Ecotourism has also led to social changes in the residents of the Kalibiru and surrounding communities. These social changes included two dimensions, namely: (1) changes in orientation at the individual farmer level; (2) orientation changes at the farmer group level.
\end{abstract}

Keywords: empowerment; social forestry; community-based ecotourism; kalibiru

\section{How to cite:}

Wiyono, Hidayat, R., \& Oktalina, S. N. (2020). The Community Empowerment Strategy in Protected Forest Management through Community-Based Ecotourism Development in Kalibiru Village , Kulon Progo Regency. HABITAT, 31(1), 11-27. https://doi.org/10.21776/ub.habitat.2020.031.1.2

\section{Introduction}

During the New Order era (1966 - 1998), the role of the state in forest management was very dominant and it was known as state-based forest management. At that time the main orientation was on the use of forest resources only to meet the industrial raw materials and exports needs. Forest management activities were carried out through logging of natural forests (timber extraction) and timber harvesting from timber plantations (Simon, 2008; 2010; Yuwono and Wiyono, 2008). The centralized and extractive forest management model during the

*Correspondence Author

E-mail: wiyono.putro@ugm.ac.id
New Order era had caused various negative impacts on the environment and local communities, including in the form of (1) Forest damage was increasingly widespread; (2) Forest biodiversity decreased; (3) Many natural disasters such as floods and landslides; (4) Local community access to forest resources was increasingly limited; (5) Local knowledge or wisdom in forest management was negated; (6) The authority of local government or customary institutions over forest resources was getting weaker; (7) The emergence of various conflicts over forest resource management (Yuwono and Wiyono, 2008; Awang, 2006).

The fall of the New Order regime had opened up opportunities for a new reconfiguration in the forestry sector in 
Indonesia, namely in the form of (1) Shifting the development paradigm from an economic growth paradigm to a populist economic paradigm, consequently, there was a change of view of the function of the forest which was originally only considered an engine of growth into a forest as a medium of social justice and income distribution; (2) The end of the authorities and the bureaucracy hegemony over civil society to create a more democratic and effective balanced polity in playing the role of social control; (3) Beginning of the empowering process in the Regional Government vis a vis of the Central Government in the autonomy and decentralization form of forestry affairs with its implementation in the resource sharing system and financial balance between the center and the regions; (4) Recognition of the rights of indigenous peoples to forest resources (Tjokrowinoto (1999). The spirit of reform had also led to a shift in forest management strategies from state-based forest management towards (1) Cooperative forest management, namely the existence of forest management cooperation between the government or forest company with communities living in the vicinity of the forest area, and (2) Community-based forest management, namely the granting of a forest management rights permit to community groups around the forest area to manage forest resources independently according to local wisdom to improve their welfare (Suhardjito, 2000; Simon, 2008; 2010; Yuwono and Wiyono, 2008).

Along with population growth and increasing community needs for forest resources, the orientation of the forest products utilization has also begun to shift from timber extraction and timber management or also called as timberbased management to (1) Forest resources management or resource-based management, namely forest management to produce timber and non-timber such as fruits, seeds, empon-empon, medicines, oil, latex, animal feed, honey, and other commercial commodities; (2) Forest ecosystem management or ecosystem-based management, namely forest management as an intact and sustainable ecosystem consisting of biotic components in the form of flora and fauna, as well as abiotic components in the form of sun, air, water, soil and rocks which are interrelated between one another (Fandeli, 2014; Simon, 2008 ; 2010). The management of this forest ecosystem does not stand alone but rather integrated with other surrounding ecosystems, such as garden ecosystems, paddy ecosystems, river ecosystems, lake ecosystems, and so forth. The management model of the surrounding forest and non-forest ecosystem in a landscape is called landscape-based management. Forests are not only seen as timber and non-timber producers but also as providers of environmental services, for example, carbon sinks, oxygen sources, clean water producers, flood prevention, erosion prevention, and landslides, habitats of various rare flora and fauna, and providers of beautiful scenery and air cool. One form of forest environmental services utilization is the development of ecotourism (Fandeli, 2014; Fandeli and Mukhlison Eds., 2000).

Ecotourism is a responsible tourism activity carried out in nature areas to preserve the environment and improve people's welfare (Fandeli and Mukhlison, Eds., 2000). According tothe United Nations Commission session results on Sustainable Development in 2000, ecotourism aimed to: (1) Ensure equal, effective and active participation from all stakeholders; (2) Ensure the participation of local residents in making decisions related to community development, land use, and regional development; (3) Raise the wisdom of the local population in controlling and maintaining natural resources (Nugroho, 2011). Ecotourism can be developed within forest areas, both production forests, protected forests, also conservation forests. Ecotourism Development in the forest area must hold the principles of conservation, education, economy, as well as community participation and empowerment. Therefore the target of ecotourism in a forest area must include: (1) Conserving the forest and its area; (2) Educating the wider community to take part in preserving the forest; (3) Improving the welfare of the local community (Fandeli and Mukhlison, Eds., 2000).

Lately, in Indonesia, there has been much development in community-based ecotourism management, which is a pattern of ecotourism development that supports and enables full involvement of local communities in the planning, implementation, and managing of ecotourism businesses with all the benefits obtained. Community-based ecotourism emphasizes the active role of local communities. This is based on the fact that local people have knowledge about nature and culture that are potential and become tourist attractions (WWF Indonesia, 2009). One example of considered successful community-based ecotourism management is the Kalibiru Nature Tourism located in Kulon Progo Regency, Special Region 
of Yogyakarta. Kalibiru Ecotourism is a form of social forestry program implementation with the Community Forest (HKm) scheme (Sudiyono, 2019; Yuwono and Novianto, 2019; Fahmi et al., 2018; Vitasurya, 2016).

There was not much research that comprehensively explored the local community empowerment strategy in the Social Forestry program of ecotourism exploitation in the protected forest areas, as well as the benefits gained by the local communities. This study specifically aimed to determine the strategies and benefits forms of empowering local communities in the management of the protected forest through the exploitation of Kalibiru Nature Tourism.

\section{Research Method}

This study was conducted in The Community Forest Farmer Group (KTHKm) of Mandiri, Kalibiru Village, Hargowilis Village, Kokap District, Kulon Progo Regency, Special Region of Yogyakarta. The field study was conducted from July to October 2019. This study used a qualitative approach. The types of data collected in this study included primary and secondary data. Primary data were collected directly by researchers at the time of the study, which included: (1) History of forest management and $\mathrm{HKm}$ licensing process in Kulon Progo Regency; (2) History of the exploitation of Kalibiru Nature Tourism by KTHKm Mandiri; (3) Stakeholders involved and their respective roles in the licensing process of $\mathrm{HKm}$ and the exploitation of Kalibiru Nature Tourism; (4) Types of rides and the amount of Kalibiru Nature Tourism rates; (5) Development of the number of visitors and income of Kalibiru Nature Tourism; (6) Forms of community empowerment strategies in the exploitation of Kalibiru Nature Tourism; (7) Kalibiru Nature Tourism exploitation benefits; (8) Forms of social change that occur in the people of Kalibiru and surrounding areas. Meanwhile, secondary data were obtained from documents related to the management of $\mathrm{HKm}$ in KTHKm Mandiri and Kalibiru Nature Tourism exploitation, which included: (1) Minister of Environment and Forestry Regulation on Social Forestry; (2) Kulon Progo Regent Decree concerning Community Forest Permits; (3) Data of farmer groups that obtain HKm licenses in Kulon Progo Regency; (4) Articles of Association and Household Budget of KTHKm Mandiri Houses;
(5) Organizational Structure of KTHKm Mandiri; (6) KTHKm Mandiri Work Plan; (7) Mechanism or rules for the distribution of KTHKm Mandiri business results.

Data were collected by (1) In-depth interview with the head of KTHKm Mandiri and the head of the LINGKAR Community; (2) Focus Group Discussion (FGD) with the head and management of KTHKm Mandiri; (3) Field observations of ecotourism management activities in protected forest areas by KTHKm Mandiri; (4) Critical review of various documents related to Kalibiru Nature Tourism exploitation by KTHKm Mandiri. The data obtained were analyzed descriptively and discussed comprehensively using relevant theoretical references and approaches.

\section{Results and Discussion}

\subsection{The Process of Community Empowerment}

During the New Order era, the management of state forest areas in Kulon Progo Regency was carried out entirely by the Yogyakarta Special Region Forest Service. With the reason to preserve the forest, the access of local people to forest resources was limited. The community was only given the right to plant palawija under intercropping for 2 years at the beginning of planting the main crop. Meanwhile, communities around forest areas that were generally classified as poor need forest resources continuously to sustain their livelihoods, such as wood to make houses, firewood for cooking, leaves for fodder, and additional arable land for food crops. After the fall of the New Order regime in 1998, many forest areas in Kulon Progo Regency were damaged by illegal logging and illegal cultivation of land by local communities.

The issuance of Law No. 41 of 1999 concerning Forestry opened opportunities for communities around the forest area to participate in forest management. In 2000, the DAMAR Foundation, with funding from The Ford Foundation, began pioneering assistance to village communities around the Kulon Progo Regency forest area. The DAMAR Foundation played an active role in raising awareness about the importance of forest conservation and encouraging community participation and empowerment in forest management. The DAMAR Foundation assisted the community in preparing institutions, improved human resource 
capacity, conducted forest mapping, prepared management plans, and various Community Forest $(\mathrm{HKm})$ permit requirements. In 2003, a temporary permit was published for $\mathrm{HKm}$ for 5 (five) years from the Kulon Progo Regent for 7 (seven) Community Forest Farmer Groups (KTHKm). Since then the community began to plant commercial trees, fruits, fodder crops, intercropping crops, and empon-empon plants under the stands. At that time, all HKm areas in Kulon Progo Regency were production forests. In 2007, based on Minister of Forestry Decree No.
437 / Menhut-II / 2007 concerning the Determination of HKm Areas in Kulon Progo Regency, part of the HKm area was changed to protected forest status. Based on the Minister of Forestry's Decree, the total forest area in Kulon Progo Regency determined as HKm area is 196.2 ha managed by seven KTHKm. The HKm area consisted of 113.8 ha of protected forest area managed by five KTHKm and 82.4 ha of production forest area managed by two KTHKm. A brief profile of the seven KTHKm in Kulon Progo Regency is presented in Table 1.

Table 1. Profile of Community Forest Farmer Groups in Kulon Progo Regency

\begin{tabular}{cclcccc}
\hline No. & $\begin{array}{c}\text { Name of } \\
\text { KTHKm }\end{array}$ & Adress of KTHKm & $\begin{array}{c}\text { IUPHKm } \\
\text { Decree No. }\end{array}$ & $\begin{array}{c}\text { Member } \\
\text { (orang) }\end{array}$ & $\begin{array}{c}\text { Area } \\
\text { (ha) }\end{array}$ & Forest Status \\
\hline 1. & Sido Akur & $\begin{array}{l}\text { Ds. Hargowilis, Kec. } \\
\text { Kokap }\end{array}$ & $450 /$ Kpts/2007 & 66 & 20 & $\begin{array}{c}\text { Protected } \\
\text { Forest }\end{array}$ \\
\hline 2. & Menggerejo & $\begin{array}{l}\text { Ds. Hargowilis, Kec. } \\
\text { Kokap }\end{array}$ & $451 / \mathrm{Kpts} / 2007$ & 60 & 11,2 & $\begin{array}{c}\text { Protected } \\
\text { Forest }\end{array}$ \\
\hline 3. & Mandiri & $\begin{array}{l}\text { Ds. Hargowilis, Kec. } \\
\text { Kokap }\end{array}$ & $452 / \mathrm{Kpts} / 2007$ & 103 & 29 & $\begin{array}{c}\text { Protected } \\
\text { Forest }\end{array}$ \\
\hline 4. & Suko Makmur & $\begin{array}{l}\text { Ds. Sendangsari, } \\
\text { Kec. Pengasih }\end{array}$ & $453 / \mathrm{Kpts} / 2007$ & 51 & 15 & $\begin{array}{c}\text { Protected } \\
\text { Forest }\end{array}$ \\
\hline 5. & Rukun Makaryo & $\begin{array}{l}\text { Ds. Sendangsari, } \\
\text { Kec. Pengasih }\end{array}$ & $454 / \mathrm{Kpts} / 2007$ & 102 & 38,6 & $\begin{array}{c}\text { Protected } \\
\text { Forest }\end{array}$ \\
\hline 6. & Taruna Tani & $\begin{array}{l}\text { Ds. Hargorejo, } \\
\text { Kec. Kokap }\end{array}$ & $449 / \mathrm{Kpts} / 2007$ & 165 & 43,4 & $\begin{array}{c}\text { Production } \\
\text { Forest }\end{array}$ \\
\hline 7. & Nuju Makmur & $\begin{array}{l}\text { Ds. Hargorejo, } \\
\text { Kec. Kokap }\end{array}$ & $448 / \mathrm{Kpts} / 2007$ & 36 & 39 & $\begin{array}{c}\text { Production } \\
\text { Forest }\end{array}$ \\
\hline & Jumlah & & $\mathbf{5 8 3}$ & $\mathbf{1 9 6 , 2}$ & \\
\hline
\end{tabular}

Source: The results of interviews and FGDs with the management of KTHKm Mandiri, as well as a review of documents for the RKU-HKm KTHKm Mandiri for 2018 Period.

Based on the Minister of Forestry Decree No. 437 / Menhut-II / 2007 concerning the Determination of HKm Areas in Kulon Progo Regency, then the Regent of Kulon Progo issued definitive $\mathrm{HKm}$ licenses for 35 years to seven KTHKm. Based on the Regent of Kulon Progo Decree No. 452 / KPTS / 2007 concerning the Business Permit for the Utilization of Community Forest Products (IUPHKm), KTHKm Mandiri was given the right to manage a protected forest area of 29 ha. Administratively, the Kalibiru protected forest area was in plots 28 and 29, Sermo Forest Management Resort $(\mathrm{RPH})$, Kulon Progo Forest Area (BDH), and Yogyakarta Forest Management Unit (KPH). The Kalibiru protected forest is located at 450 meters above sea level in the southern part of the Menoreh Hills. The peak of the Kalibiru protected forest has beautiful natural scenery, namely the canopy of lush and green protected forest trees, Sermo Reservoir with blue water to the west, and Menoreh Hills to the north.
Kalibiru nature tourism exploitation was pioneered by the LINGKAR Community (Community Care for Sustainable Natural Environment), a consortium of seven KTHKm located in Kulon Progo Regency. In 2008, the LINGKAR Community took the initiative to submit a proposal to the Regional Government of Kulon Progo Regency to develop nature tourism in the Kalibiru protected forest area managed by KTHKm Mandiri. The construction of physical facilities for the Kalibiru Nature Tourism began to be built at the end of 2008 after receiving funding from the Kulon Progo Regional Government. Initially, the Kalibiru Nature Tourism exploitation was an outlet for the disappointment of the KTHKm Mandiri over the change in the status of the forest area from production forest to protected forest, so that they were not allowed to cut timber. The hope of KTHKm Mandiri members to get the profitsharing from the harvesting of the timber they planted had vanished. Over time, the exploitation 
of Kalibiru Nature Tourism by KTHKm Mandiri continued to grow.

\subsection{Community Empowerment Strategy}

In general, the forest village community empowerment strategies undertaken by KTHKm Mandiri through community-based ecotourism development included (1) Institutional management strategies; (2) Forest area management strategy; and (3) Forest management business strategy. A description of each of these strategies was as follows:

\section{a. Institutional management strategy}

KTHKm Kalibiru was established on December 25, 2001. The number of KTHKm Mandiri members was 103 people. KTHKm Mandiri membership was either individual or voluntary. The members of KTHKm Mandiri were initially members of the livestock farmer groups and illegal cultivators of forest land. Under the Kulon Progo Regent Decree No. 452 / KPTS / 2007 dated 12 December 2017, KTHKm Mandiri and its members had the following rights: (1) Conducting forest utilization business; (2) Utilizing land under stands or between staple crops; (3) Utilizing non-timber forest products; (4) Utilizing animal feed; (5) Utilizing environmental services; (6) Getting assistance and empowerment from the government, NGOs, universities, or other parties; (7) Getting facilitation and funding assistance from the government or other parties in forest management; (8) Getting the results of the group effort.

Meanwhile, the obligations of KTHKm Mandiri and its members according to the regent's decree were at least the following: (1) Planting staple and estate crops plants; (2) Maintaining the security of the forest along with the trees in it; (3) Carrying out an inventory or number each tree; (4) Not allowed to transfer the $\mathrm{HKm}$ management permit; (5) Preparing HKm management plans; (6) Implementing group work programs; (7) Carrying out forest management according to local wisdom; (8) Reporting forest management activities to the forestry agency.

KTHKm Mandiri had a management structure consisting of: (1) Protectors from the Village Government; (2) Advisors; (3) Supervisors; (4) Management, which consisted of the head, secretary, treasurer, and sections; (5) Business units. KTHKm Mandiri had three business units, namely: (1) Cooperative business unit; (2) Environmental services business unit; (3) Animal husbandry business units. Kalibiru Ecotourism was part of the environmental services business unit. The organizational structure of KTHKm Mandiri is presented in Figure 1.

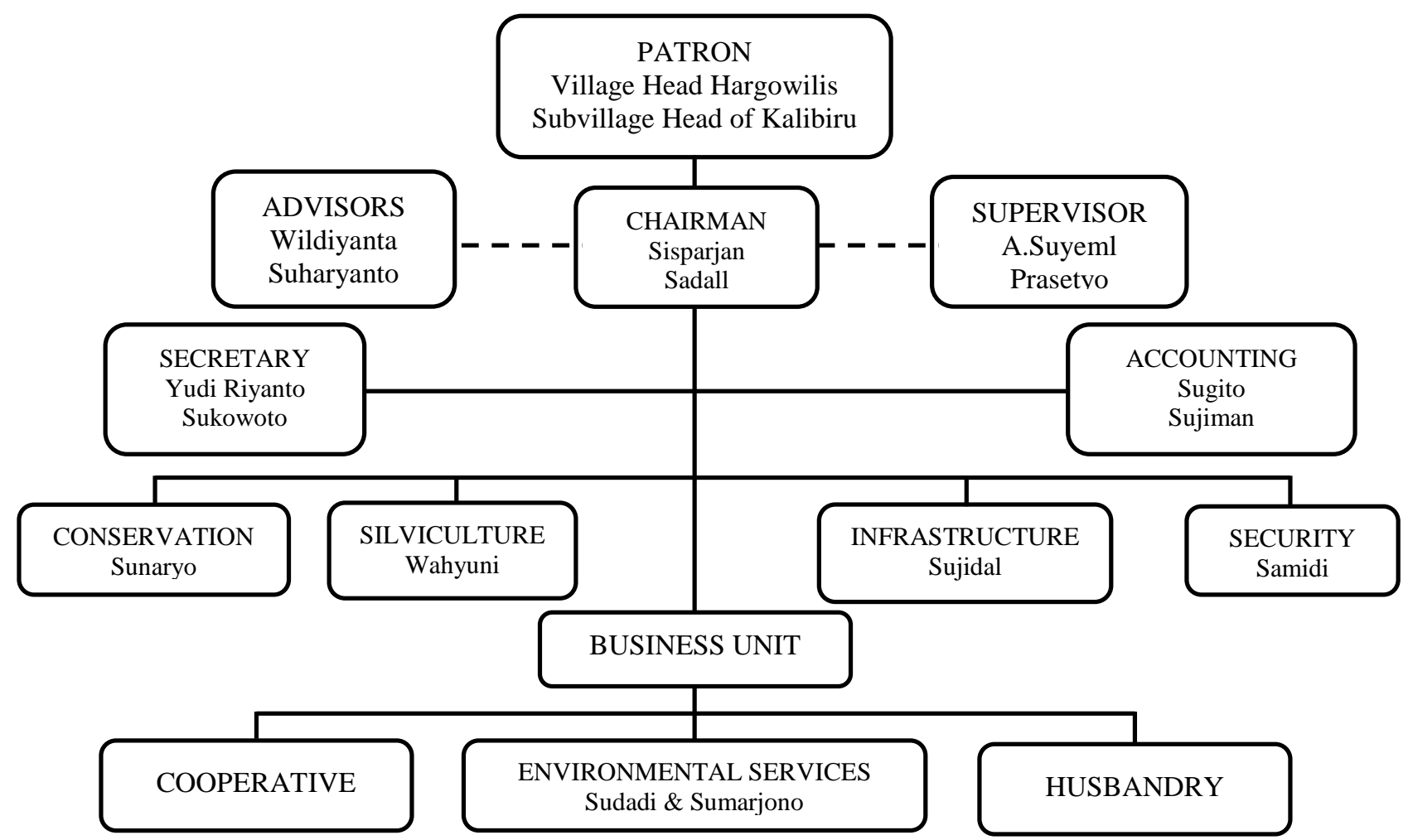

Source: The Internal Regulation of KTHKm Mandiri; Fahmi et al., 2018.

Figure 1. KTHKm Mandiri Organizational Structure

Available online at HABITAT website: http://www.habitat.ub.ac.id

ISSN: 0853-5167 (p); 2338-2007 (e) 
KTHKm Mandiri already had Articles of Association and Bylaws as formal rules and guidelines in the organization of institutions. However, KTHKm Mandiri was not rigid in applying these formal regulations. KTHKm Mandiri prioritized the informal approach and example of group management in managing the institution. KTHKm Mandiri also had the Community Forest Business Work Plan (RKU$\mathrm{HKm}$ ) document for 10 years, namely the period of 2018-2027. Then, the RKU-HKm document was used as a guideline for compiling the Annual Community Forest Utilization Business Plan (RKT-UPHKm). Broadly speaking, KTHKm Mandiri's work plan in 2019 included: (1) Forest conservation, protection, and security plan; (2) Plans for the utilization and collection of nontimber forest products; (3) Forest area utilization plan, in the form of animal feed cultivation and empon-empon; (4) Utilization of environmental services, in the form of ecotourism; (5) Group business development, including raising cattle, all-round cooperatives, and environmental services; (6) Institutional development, including regular meetings of group members, business units, LINGKAR Communities, and organizational administration. The implementation of the KTHKmm Mandiri work program was not solely results-oriented but more process-oriented and member participation. The management and members always work together in carrying out the work program KTHKm Mandiri. This was done to maintain group cohesiveness and harmonious relationships between group members.
KTHKm Mandiri had wide networking with various related parties (stakeholders). Related to the development of Kalibiru Nature Tourism, the stakeholders could generally be grouped into three, namely: main stakeholders, primary stakeholders, and secondary stakeholders. Main stakeholders were the key actors in managing $\mathrm{HKm}$ and the main beneficiaries of the Kalibiru Nature Tourism existence. Main stakeholders included head, managements, employees, and members of KTHKm Mandiri. Primary stakeholders were those who had a direct contribution to the process of issuing the $\mathrm{HKm}$ Mandiri permit and the development of Kalibiru Nature Tourism. Primary stakeholders included NGOs (DAMAR and JAVLEC Foundation), LINGKAR Community, The Village Government of Hargowilis, The Regional Government of Kulon District, The Environment and Forestry Department of Yogyakarta Special Region (DIY), The Yogyakarta Forest Management Unit $(\mathrm{KPH})$, The Ministry of Environment and Forestry. Secondary stakeholders were those who had an indirect contribution to the KTHKm Mandiri and/or beneficiaries of Kalibiru Nature Tourism existence. Secondary stakeholders included donor foundations, Kalibiru and surrounding village communities, tourist visitors, travel and event organizer companies, the central government, universities and research centers, the media, and The Environmental care companies. The form of interaction and the role of each stakeholder in the management of Kalibiru Nature Tourism are presented in Table 2 and Figure 2.

Table 2. The role of stakeholders in the Kalibiru Nature Tourism management

\begin{tabular}{|c|l|l|}
\hline No. & \multicolumn{1}{|c|}{ Stakeholders } & \multicolumn{1}{|c|}{ Roles } \\
\hline A. & Main Stakeholders & $\begin{array}{l}\text { Main stakeholders are the key actors in managing HKm and the } \\
\text { main beneficiaries of Kalibiru Nature Tourism existence. }\end{array}$ \\
\hline 1. & $\begin{array}{l}\text { Head of KTHKm } \\
\text { Mandiri }\end{array}$ & $\begin{array}{l}\text { Head of KTHKm Mandiri has roles to lead the initiation, plan, } \\
\text { coordinate, manage, and evaluate all of KTHKm Mandiri activities, as } \\
\text { well as build the external networks. }\end{array}$ \\
\hline 2. & $\begin{array}{l}\text { Management of } \\
\text { KTHKm Mandiri }\end{array}$ & $\begin{array}{l}\text { Management of KTHKm Mandiri has roles to plan, manage, promote, } \\
\text { and document KTHKm Mandiri activities. }\end{array}$ \\
\hline 3. & $\begin{array}{l}\text { Staff of the Nature } \\
\text { Tourism Business } \\
\text { Unit }\end{array}$ & $\begin{array}{l}\text { Staff of the Nature Tourism Business Unit, As Professional staffs to } \\
\text { implement KTHKm Mandiri programs, especially related to Kalibiru } \\
\text { Nature Tourism Business. }\end{array}$ \\
\hline 4. & $\begin{array}{l}\text { Member of KTHKm } \\
\text { Mandiri }\end{array}$ & $\begin{array}{l}\text { Member of KTHKm Mandiri has roles to help the head in implementing } \\
\text { the programs along with the managements and staff. It also becomes the } \\
\text { main source or workers for KTHKm Mandiri. }\end{array}$ \\
\hline B. & $\begin{array}{l}\text { Primary } \\
\text { Stakeholders }\end{array}$ & $\begin{array}{l}\text { Primary Stakeholders are some parties that contributed directly to the } \\
\text { permit publication process of HKm Mandiri and Kalibiru Nature }\end{array}$ \\
\hline
\end{tabular}




\begin{tabular}{|c|c|c|}
\hline No. & Stakeholders & Roles \\
\hline & & Tourism development. \\
\hline 1. & $\begin{array}{l}\text { NGO (DAMAR } \\
\text { Foundation r dan } \\
\text { JAVLEC) }\end{array}$ & $\begin{array}{l}\text { DAMAR Foundation is an environmental and community empowerment } \\
\text { NGO which assists KTHKm Mandiri tp obtain permission in managing } \\
\text { the Community Forest. Meanwhile, JAVLEC (Java Learning Center) } \\
\text { aims to conduct Kalibiru Nature Tourism teaching, study, and } \\
\text { promotion. }\end{array}$ \\
\hline 2. & $\begin{array}{l}\text { LINGKAR } \\
\text { Community }\end{array}$ & $\begin{array}{l}\text { LINGKAR community is a consortium of seven KTHKm in Kulon } \\
\text { Progo Regency. This community has a role as the first institution which } \\
\text { asking for funding help to the Kulon District Government to construct } \\
\text { Kalibiru Nature Tourism facilities. }\end{array}$ \\
\hline 3. & $\begin{array}{lr}\text { The } & \text { Village } \\
\text { Government } & \text { of } \\
\text { Hargowilis } & \\
\end{array}$ & $\begin{array}{l}\text { The Village Government of Hargowilis has a role to give } \\
\text { recommendation related to } \mathrm{HKm} \text { permit and become the protector for } \\
\text { KTm Mandiri institutionally. }\end{array}$ \\
\hline 4. & $\begin{array}{l}\text { The Regional } \\
\text { Government of } \\
\text { Kulon Progo District }\end{array}$ & $\begin{array}{l}\text { The Regional Government of Kulon Progo Regency, in this case, the } \\
\text { Regent has a role in giving HKm definite permits to KTHKm Mandiri, as } \\
\text { well as providing financial assistance for the construction of tourist } \\
\text { facilities. }\end{array}$ \\
\hline 5. & $\begin{array}{lr}\text { Department } & \text { of } \\
\text { Environment } & \text { and } \\
\text { Forestry, } & \mathrm{KPH} \\
\text { Yogyakarta } & \end{array}$ & $\begin{array}{l}\text { Department of Environment and Forestry DIY, as well as KPH } \\
\text { Yogyakarta DIY as the holder of the DIY region forest area in the DIY } \\
\text { region, has the role in providing technical guidance on forest planning } \\
\text { and management, ratification of forest management plan documents } \\
\text { (RKU and RKT) also evaluating the performance of KTHKm Mandiri. }\end{array}$ \\
\hline 6. & $\begin{array}{lr}\text { Ministry } & \text { of } \\
\text { Environment and } \\
\text { Forestry }\end{array}$ & $\begin{array}{l}\text { Ministry of Environment and Forestry is an institution that sets the } \\
\text { location of state forest areas as HKm program areas in Kulon Progo } \\
\text { Regency. Ministry of Environment and Forestry also plays a role in } \\
\text { providing guidance and promotion of Kalibiru HKm management. }\end{array}$ \\
\hline C. & $\begin{array}{l}\text { Secondary } \\
\text { Stakeholders }\end{array}$ & $\begin{array}{l}\text { Secondary stakeholders are those who have an indirect contribution to } \\
\text { the KTHKm Mandiri and / or beneficiaries of the Kalibiru Nature } \\
\text { Tourism existence. }\end{array}$ \\
\hline 1. & Donor Foundations & $\begin{array}{l}\text { Donor foundations such as The Ford Foundation and other donor } \\
\text { agencies play a role in providing financial assistance to support the } \\
\text { DAMAR Foundation and JAVLEC activities in assisting communities } \\
\text { and promoting Kalibiru Nature Tourism. }\end{array}$ \\
\hline 2. & $\begin{array}{l}\text { Kalibiru and } \\
\text { surrounding } \\
\text { communities }\end{array}$ & $\begin{array}{l}\text { Kalibiru and surrounding communities play a role as providers of labor } \\
\text { and Kalibiru Nature Tourism beneficiaries, for example in the form of } \\
\text { tourism employees, food stall owners, parking lot providers, } \\
\text { transportation service providers such as motorcycle taxis and jeeps. }\end{array}$ \\
\hline 3. & $\begin{array}{l}\text { Kalibiru Nature } \\
\text { Tourism Visitors }\end{array}$ & $\begin{array}{l}\text { Kalibiru Nature Tourism visitors play a role in promoting through social } \\
\text { media by uploading interesting photos on social media and } \\
\text { recommending to friends and relatives to visit Kalibiru }\end{array}$ \\
\hline 4. & $\begin{array}{l}\text { Travel and Event } \\
\text { Organizer Company }\end{array}$ & $\begin{array}{l}\text { Travel and Event Organizer Company has a role in promoting and } \\
\text { inviting tourists to visit Kalibiru Nature Tourism. }\end{array}$ \\
\hline 5. & Central Government & $\begin{array}{l}\text { Central Government has a role in providing infrastructure such as road } \\
\text { construction as well as funds for village development through the Kulon } \\
\text { Progo Regency government. }\end{array}$ \\
\hline 6. & $\begin{array}{l}\text { Universities and } \\
\text { Research Centers }\end{array}$ & $\begin{array}{l}\text { Universities and research centers through academics and researchers play } \\
\text { a role in conducting studies, community service, and promotion of the } \\
\text { existence of Kalibiru Nature Tourism. }\end{array}$ \\
\hline 7. & Media & $\begin{array}{l}\text { Media has a role in promoting Kalibiru Nature Tourism through articles } \\
\text { or news posted on websites, social media, newspapers, magazines, radio, } \\
\text { television, YouTube and other media. }\end{array}$ \\
\hline 8. & Environmental Care & Environmental care companies play a role in providing CSR funding for \\
\hline
\end{tabular}




\begin{tabular}{|l|l|l|}
\hline No. & \multicolumn{1}{|c|}{ Stakeholders } & \multicolumn{1}{c|}{ Roles } \\
\hline & Company & the development of Kalibiru Nature Tourism \\
\hline
\end{tabular}

Source: The Result Analysis of Primary and Secondary Data, 2019

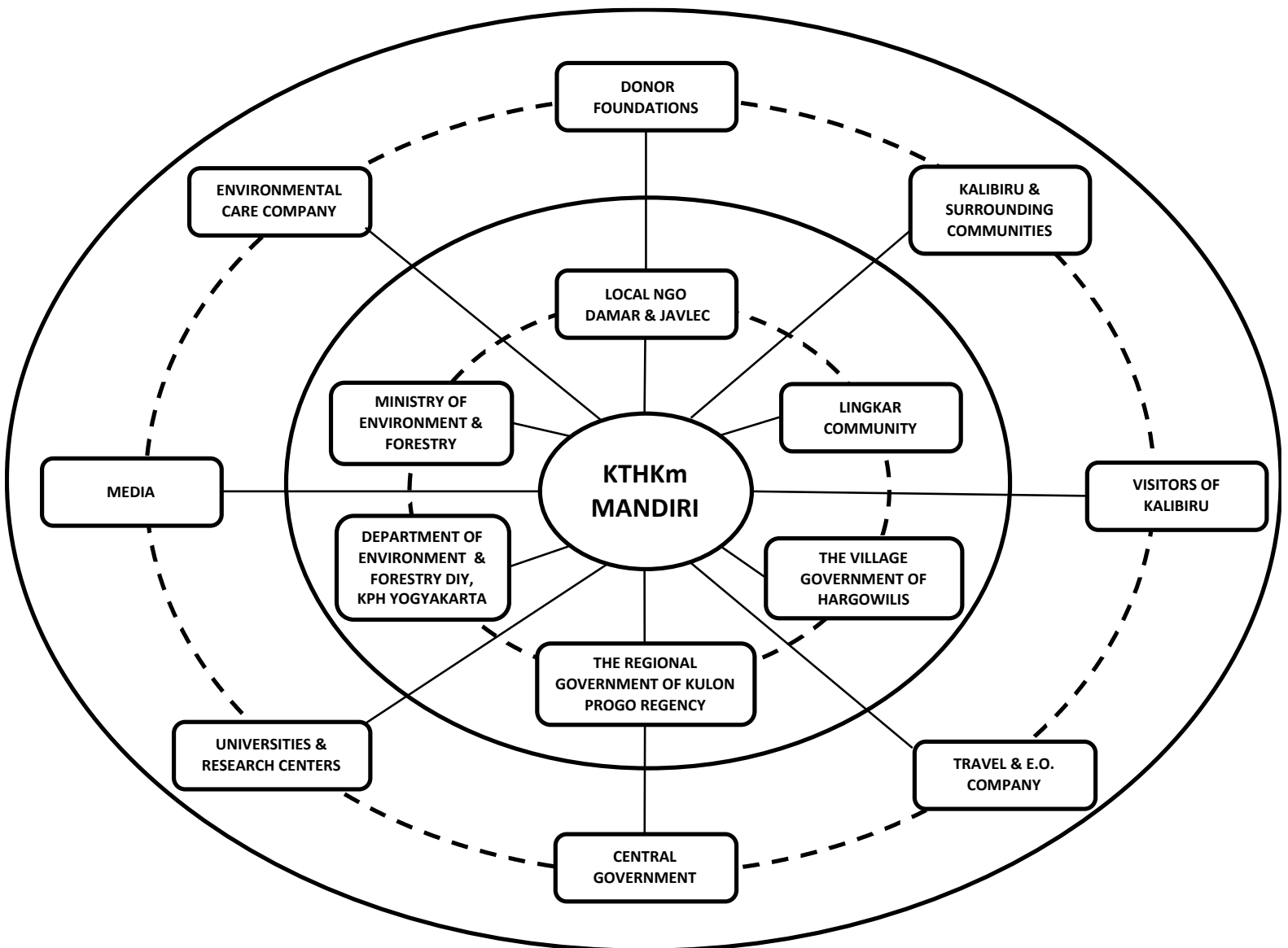

Description: : direct interaction; ------: indirect interaction

Source: Results of primary and secondary data analysis, 2019.

Figure 2. Interaction between Stakeholders in the management of Kalibiru Nature Tourism

\section{b. Forest area management strategy}

According to the Minister of Environment and Forestry Regulation No. P.83 / MENLHK / SETJEN / KUM.1 / 10/2016 concerning Social Forestry, the use of forests by KTHKm Mandiri in the Kalibiru protected forest area was limited to (1) Utilization of non-timber forest products; (2) Utilization of forest areas; (3) Utilization of environmental services. KTHKm Mandiri was not allowed to cut trees in protected forest areas, even though the trees were the result of community plants in the past. The provision was also confirmed by the Decree of the Kulon Progo Regent No. 452 / KPTS / 2007 concerning Business Permit for the Utilization of Community Forest Products (IUPHKm) to KTHKm Mandiri.
At the beginning of the KTHKm Mandiri formation, mapping and boundary of forest areas were carried out in the HKm area. The protected forest area of 29 ha had been divided into the share of utilization to all members of KTHKm Mandiri. With a total membership of 103 people, each member of KTHKm Mandiri received an average share of 0.25 ha of land. However, there were some members of KTHKm Mandiri who had acquired more than 0.25 ha of land as compensation for their services to group development. Each KTHKm Mandiri member was required to plant and maintain trees on their respective land. Each member of KTHKm Mandiri was given the right to use non-timber forest products and forage crops, palawija or empon empon under the stands. At that time, additional arable land in the 
forest was the main attraction for becoming a member of KTHKm Mandiri. As forest stands grow, yields from the share of land were diminishing, because the types of plants that could live in shade were increasingly limited. As a result, a lot of lands were left behind and no longer used by KTHKm Mandiri members. Many KTHKm members had switched from land tenants to nature tourism managers.

KTHKm Mandiri had 2019 Annual Work Plan (RKT) documents. According to the RKT document, the 29 ha Kalibiru protected forest area was divided into seven utilization blocks, namely Besole, Munggang, Papon, Watu Tumpeng, Watu Eyup, Krasak, and Kali times. Bengkup. In general, the utilization of Kalibiru protected forest area by KTHKm Mandiri included (1) Utilization of non-timber forest products; (2) Utilization of plants under the stands; (3) Utilization of environmental services. The utilization of non-timber forest products such as planting fruit plants like avocados, jackfruit, and candlenut. Land use under the stands was done by planting shade-resistant plants to produce animal feed and high-value empon empon, such as ginger, galangal, kaempferia galanga, ginger, and lemongrass. Meanwhile, the utilization of environmental services was carried out through the exploitation of natural selfie spots. The distribution of blocks and directions for the use of protected forest areas by KTHKm Mandiri is presented in Table 3.

Table 3. Distribution of protected forest area utilization block in KTHm Mandiri

\begin{tabular}{|c|c|c|c|}
\hline No. & Name of Block & Utilization Activities & Information \\
\hline 1. & Blok I Besole & $\begin{array}{l}\text { Utilization of non-timber forest } \\
\text { products and land under the stands }\end{array}$ & $\begin{array}{l}\text { Planted with fruit trees, empon- } \\
\text { empon and forage }\end{array}$ \\
\hline 2. & Blok II Munggang & $\begin{array}{l}\text { Utilization of non-timber forest } \\
\text { products, land under the stands, and } \\
\text { environmental services }\end{array}$ & $\begin{array}{l}\text { Planted with fruit trees, empon- } \\
\text { empon, forage, and environmental } \\
\text { services }\end{array}$ \\
\hline 3. & Blok III Papon & $\begin{array}{l}\text { Utilization of non-timber forest } \\
\text { products, land under the stands, and } \\
\text { environmental services }\end{array}$ & $\begin{array}{l}\text { Planted with fruit trees, empon- } \\
\text { empon, forage, and environmental } \\
\text { services }\end{array}$ \\
\hline 4. & $\begin{array}{l}\text { Blok IV Watu } \\
\text { Tumpeng }\end{array}$ & $\begin{array}{l}\text { Utilization of non-timber forest } \\
\text { products and land under the stands }\end{array}$ & $\begin{array}{l}\text { Planted with fruit trees, empon- } \\
\text { empon and forage }\end{array}$ \\
\hline 5. & Blok IV Watu Eyup & $\begin{array}{l}\text { Utilization of non-timber forest } \\
\text { products and land under the stands }\end{array}$ & $\begin{array}{l}\text { Planted with fruit trees, empon- } \\
\text { empon and forage }\end{array}$ \\
\hline 6. & Blok VI Krasak & $\begin{array}{l}\text { Utilization of non-timber forest } \\
\text { products and land under the stands }\end{array}$ & $\begin{array}{l}\text { Planted with fruit trees, empon- } \\
\text { empon and forage }\end{array}$ \\
\hline 7. & $\begin{array}{l}\text { Blok VII Kali } \\
\text { Bengkung }\end{array}$ & $\begin{array}{l}\text { Utilization of non-timber forest } \\
\text { products and land under the stands }\end{array}$ & $\begin{array}{l}\text { Planted with fruit trees, empon- } \\
\text { empon and forage }\end{array}$ \\
\hline
\end{tabular}
Source: RKT-KTHKm Mandiri Documents, 2019.

Currently, KTHKm Mandiri was more focused on developing the use of environmental services through nature tourism. However, the protected forest area utilized for the development of nature tourism facilities was not more than 2 ha or less than $10 \%$ of the HKm permit total area. Most of the Kalibiru protected forest area was still in the form of forests which were overgrown with various types of trees such as acacia (Acacia auriculiformis), teak (Tectona grandis), mahogany (Swietenia mahagoni), gmelina (Gmelina arborea), sono (Dalbergia latifolia), and pine (Pinus grandis), mahogany (Swietenia mahagoni), gmelina (Gmelina arborea), sono (Dalbergia latifolia), and pine (Pinus merkusii). The trees were not cut down but only taken the environmental benefits, namely as a producer of clean air, carbon sinks, regulating water systems, prevent landslides, and providers of beautiful scenery. Meanwhile, for the purpose of springs conservations, KTHKm Mandiri also planted around springs with various types of trees such as tamarind (Tamarindus indica), banyan (Ficus benjamina), gayam (Inocarpus fagifer), and various other local tree species.

\section{c. Forestry business management strategy}

KTHKm Mandiri had three types of business units, namely: (1) Cooperative business units; (2) Livestock business unit; (3) Environmental services business unit. Among the three types of businesses, the most advanced was environmental service businesses through the operation of Kalibiru Nature Tourism. Kalibiru Nature Tourism Management focused on the 
utilization of protected forest environmental services with photo spots as the main attraction. This photo spot tour was considered environmentally friendly because it only took the benefits of the forests in the form of natural scenery without damaging or cutting down trees. The tourism object offered to visitors was the experience of taking pictures above the height against the backdrop of the beautiful scenery of the Kalibiru protected forest and Sermo Reservoir. Currently, in the Kalibiru Nature Tourism area, there were 10 (ten) photo spots consisting of 3 (three) tree spots, 3 (three) nontree spots, 1 (one) bicycle spot, 1 (one) hang gliding spot, 1 (one) canoe spot, and 1 (one) swing spot. Moreover, at the Kalibiru Nature Tourism location, there were also other attractions such as High Rope Game, Flying Fox, and Tracking. The entrance ticket to Kalibiru Nature Tourism was IDR 10,000 / person for domestic tourists and IDR 20,000 / person for foreign tourists. Each photo spot's price was varied between Rp. 10,000 to Rp. 30,000 / person. Kalibiru Nature Tourism visitors could take pictures using either their own camera/cell phone or with the help of photographer services provided by the tour manager with the price of Rp 5,000 / photo.



Source: The Results of Interview and FGD with the management of KTHKm Mandiri, 2019.

Figure 3. Progress of visitor numbers at the Kalibiru Nature Tourism

In 2010, Kalibiru Nature Tourism became known to the public. Based on the data in Figure 3, in 2010 - 2013 the number of Kalibiru Nature Tourism visitors tended to increase, from 7,167 people (2010) to 13,039 people (2011), to 19,012 people (2012), and to 19,762 people (2013). In 2014 , there were an increasing number of visitors up to $300 \%$ compared to 2013 , which reached 79,137 people. In 2015, it also increased by $291 \%$ to 309,541 people. The number of visitors reached its peak in 2016, reaching 443,070 people. The increasing number of visitors to Kalibiru Nature Tourism was an impact of selfie photos trends in millennials, then uploading them to social media such as Facebook, Instagram, WhatsApp, Twitter, Line, and so on. Then in 2017 and 2018 the number of Kalibiru Nature Tourism visitors tended to decrease, namely to 355,498 people in 2017 and decreased again to 183,498 people in 2018 . The declining number of Kalibiru Nature Tourism visitors occurred because of many similar natural attractions in the Yogyakarta Special Region and its surroundings, such as Canting Mas Nature Tourism in Kulon Progo, Pinus Mangunan in Bantul, Nglanggeran in Gunungkidul, and Punthuk Setumbu in Magelang. 


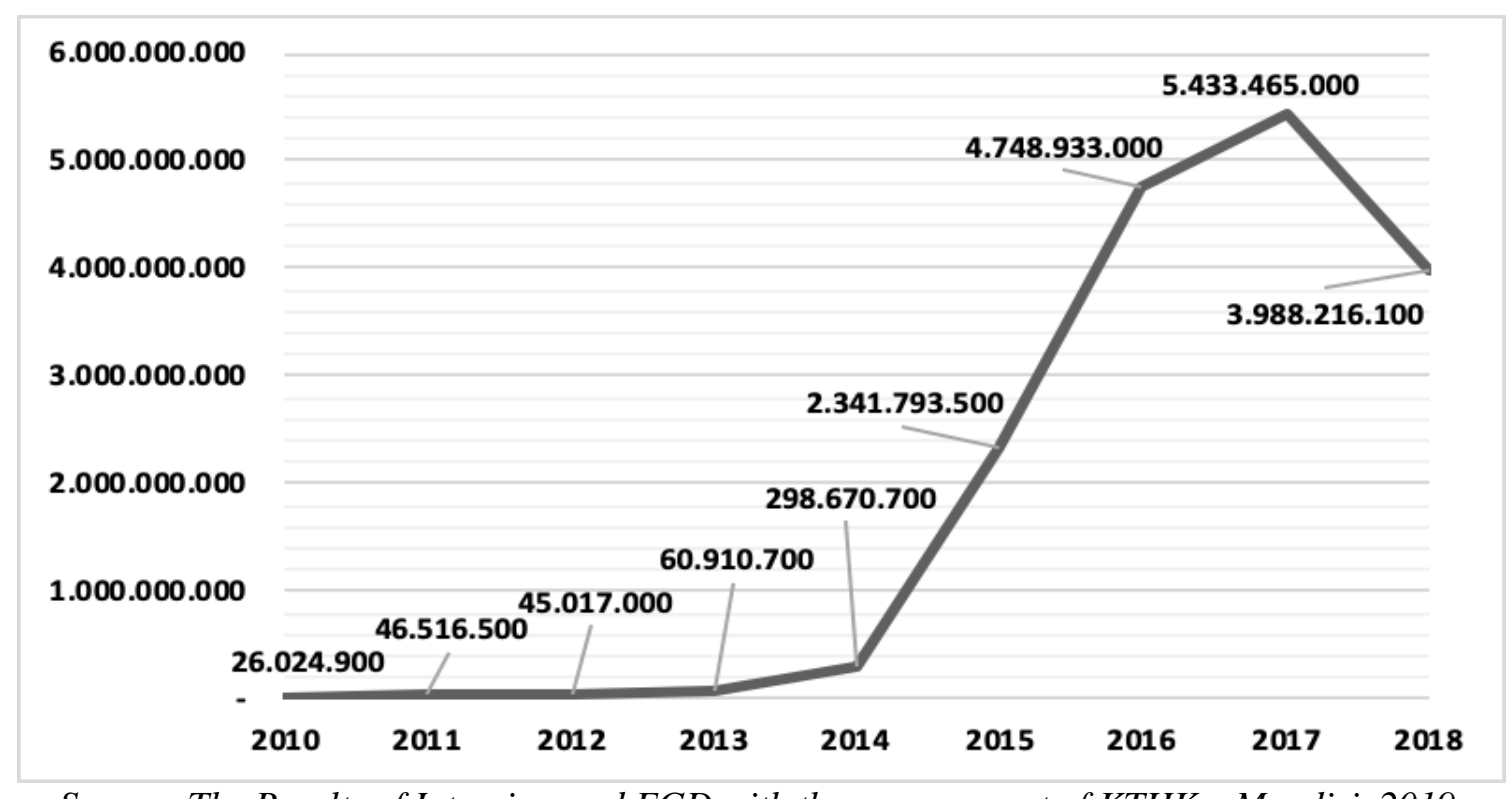

Source: The Results of Interview and FGD with the management of KTHKm Mandiri, 2019.

Figure 4. Development of Kalibiru Nature Tourism revenue

Based on the data in Figure 4, the KTHKm Mandiri's revenue from the Kalibiru Nature Tourism management tended to increase in 20102017. In 2010, Kalibiru Nature Tourism revenue was only $\mathrm{Rp} 26,024,900$, then increased to $\mathrm{Rp}$ $46,516,500$ in 2011 , decreased again to IDR $45,017,000$ in 2012, and increased to IDR $60,910,500$ in 2013. In 2014, the Kalibiru Nature Tourism revenue increased sharply 390\% compared to the previous year reached IDR $298,670,700$. In 2015 , its revenue jumped $684 \%$ to $\mathrm{Rp} 2,341,793,000$ and increased again $103 \%$ to $\mathrm{Rp} 4,748,933,000$ in 2016. The increase in Kalibiru Nature Tourism revenue in 2010-2016 occurred due to an increasing number of visitors as presented in Figure 3. While, in 2017 the number of visitors in Kalibiru Nature Tourism decreased by $20 \%$ from the previous year, but the revenue increased by $14 \%$ to $\mathrm{Rp} 5,433,465,000$. It happened because the Kalibiru Nature Tourism management had added a lot of new photo spots as an income enhancer. Meanwhile, the number of visitors decreased by $48 \%$ in 2018, while revenues also decreased by $27 \%$ to $\mathrm{Rp}$ $3,988,216,100$. It occurred because the number of competitors in identical natural attractions in the Yogyakarta Special Region and surrounding areas was increasing.

\subsection{Benefits of community empowerment}

KTHKm Mandiri had determined the proportion of the group business results distribution in the Bylaws document. The allocation of the KTHKm Mandiri's operating funds was broadly divided into two, namely: (1) The portion for KTHKm Mandiri management was $80 \%$; (2) The portion for the tourism business unit was $20 \%$. The existence of KTHKm Mandiri did not only benefit the management and group members, but also the local community. This was reflected by the allocation of environmental development funds of $5 \%$, social funds of $5 \%$ and Community LINGKAR funds of $2.5 \%$. The allocation of these funds was a form of KTHKm Mandiri's social responsibility towards the Kalibiru and surrounding communities. The funds for the environment development were used to help the repairing roads costs between damaged houses, the worship houses and other public facilities maintanance. Social funds were used to help the effect of natural disasters, house renovations for the poor, compensation for orphans and elderly people, as well as assistance for social, artistic and religious activities organized by the Kalibiru community. Meanwhile, the allocation of funds for the LINGKAR Community was a form of appreciation and proof of KTHKm Mandiri's solidarity with other $\mathrm{HKm}$ farmer groups who had been instrumental in pioneering the operation of Kalibiru Nature Tourism. The funds were used to finance the LINGKAR Community acivities, such as regular monthly meetings, human resources development, and other KTHKm developments. The allocation details of the business results income in KTHKm Mandiri are presented in Table 4. 
Table 4. Allocation of Kalibiru Nature Tourism business results distribution

\begin{tabular}{clc}
\hline No. & Allocation of Business Results Distribution & Percentage (\%) \\
\hline A. & KTHKm Mandiri Management & \\
1. Forest Sustainability Fund & $5 \%$ \\
2. Operational KTHKm Mandiri & $10 \%$ \\
3. Environmental Development & $5 \%$ \\
4. Pioneer services & $7,5 \%$ \\
5. Member services & $10 \%$ \\
6. Social Funds & $5 \%$ \\
7. Circular community & $2,5 \%$ \\
8. Procurement of facilities & $30 \%$ \\
9. Others & $5 \%$ \\
\hline & & $\mathbf{8 0 \%}$ \\
\hline B & Tourism Business Unit & $15 \%$ \\
1. Repair/maintenance tools & Total & $5 \%$ \\
\hline 2. Promotion/publication costs & & $\mathbf{2 0 \%}$ \\
\hline
\end{tabular}

Source: KTHKm Mandiri Household Bylaws, 2019.

The existence of Kalibiru Nature Tourism provided economic benefits to the people of Kalibiru Village including employment, business opportunities, and profit-sharing. New jobs created include KTHKm administrators, tour managers, permanent employees, photo spot guide freelance employees, freelance road guide employees, jeep drivers, motorcycle taxi drivers, stall employees, and parking attendants. New business fields created included stalls, both located in and around tourist sites, parking lot services, jeep transportation businesses, and homestays. All KTHKm Mandiri members also received profit-sharing from the ecotourism business. The benefits of Kalibiru Nature Tourism existence were also felt by residents outside the Kalibiru village in the form of business opportunities for jeep transportation services, motorcycle taxis, travel and event organizers. In Table 5, the community of Kalibiru Village who get the benefit from the ecotourism existence.

Table 5. Beneficiaries of Kalibiru Nature Tourism

\begin{tabular}{|c|c|c|}
\hline No & Beneficiaries & Amount (People) \\
\hline \multirow[t]{8}{*}{ A. } & Inside tourism area & \\
\hline & 1. The Management of KTHKm Mandiri & 15 \\
\hline & 2. Kalibiru Nature Tourism Manager & 7 \\
\hline & 3. Permanent staffs & 63 \\
\hline & 4. Freelance staffs as photo guides & 28 \\
\hline & 5. Freelance staffs as tour guides & 16 \\
\hline & 6. Stall owners and employees & 41 \\
\hline & Total & 170 \\
\hline \multirow[t]{8}{*}{ B. } & Outside tourism area & \\
\hline & 1. Home Stay & 4 \\
\hline & 2. Restaurant & 6 \\
\hline & 3. Parking Services & 9 \\
\hline & 4. Motorcycle Taxi Services & 15 \\
\hline & 5. Jeep Services & 15 \\
\hline & 6. Tour Guides Services & 2 \\
\hline & Total & 51 \\
\hline C. & Farmers (KTHKm members) who get profit sharing & 103 \\
\hline & Total of Beneficiaries & 324 \\
\hline
\end{tabular}

Source: The result of interview and FGD with Kalibiru Nature Tourism Management, 2019. 
Besides the economic benefits, the Kalibiru Nature Tourism service business existence by KTHKm Mandiri also had led to the social changes in the Kalibiru Village community and its surroundings behavior. The forms of social changes that occur are presented in Table 6.

Table 6. Social changes experienced by Kalibiru community after natural tourism business

\begin{tabular}{|c|c|c|}
\hline No. & Before Kalibiru Natural Tourism Business & Before Kalibiru Natural Tourism Businesss \\
\hline A. & \multicolumn{2}{|c|}{ Changes in orientation at the individual farmer level } \\
\hline 1. & $\begin{array}{l}\text { The community acts as the loggers and forest } \\
\text { loggers }\end{array}$ & $\begin{array}{l}\text { The community acts as the managers and } \\
\text { forest guards }\end{array}$ \\
\hline 2. & $\begin{array}{l}\text { The community works as forest harvesters and } \\
\text { cultivators }\end{array}$ & $\begin{array}{l}\text { The community works as employees, service } \\
\text { providers, and business owners }\end{array}$ \\
\hline 3. & $\begin{array}{l}\text { The community works and acts individually in } \\
\text { their fields }\end{array}$ & $\begin{array}{l}\text { The community works and acts together with } \\
\text { farmer groups }\end{array}$ \\
\hline 4. & $\begin{array}{l}\text { The community manages the land and uses the } \\
\text { subsistent forest products }\end{array}$ & $\begin{array}{l}\text { The community manages the area and uses the } \\
\text { forest products commercially }\end{array}$ \\
\hline B. & \multicolumn{2}{|l|}{ Changes in orientation at the farmer group level } \\
\hline 1. & $\begin{array}{l}\text { The head of the forest farmer's group acts as the } \\
\text { farmer leader with social benefits orientation }\end{array}$ & $\begin{array}{l}\text { The head of the forest farmer group acts as an } \\
\text { eco-socio entrepreneur with environmental, } \\
\text { social, and financial benefits orientation }\end{array}$ \\
\hline 2. & $\begin{array}{l}\text { The forest farmer group management carries out } \\
\text { the institution as part time }\end{array}$ & $\begin{array}{l}\text { The forest farmer group and staffs manage the } \\
\text { business unit professionally }\end{array}$ \\
\hline 3. & $\begin{array}{l}\text { The forest products used to meet the individual } \\
\text { daily needs }\end{array}$ & $\begin{array}{l}\text { The forest products used to meet the members, } \\
\text { groups, and community needs }\end{array}$ \\
\hline 4. & $\begin{array}{l}\text { There is no specific allocation of forest business } \\
\text { results to help the poor }\end{array}$ & $\begin{array}{l}\text { There is a specific allocation to help the poor } \\
\text { and orphan }\end{array}$ \\
\hline 5. & $\begin{array}{l}\text { The forest management activities only related to } \\
\text { the forestry and agriculture technical activities } \\
\text { conducted inside the forest area }\end{array}$ & $\begin{array}{l}\text { The forest management activities integrated } \\
\text { with infrastructural and rural socio-economics } \\
\text { development }\end{array}$ \\
\hline
\end{tabular}

Source: The result analysis of primary and secondary data, 2019.

\subsection{Discussion}

According to data from the Ministry of Environment and Forestry (KLHK, 2018), the number of villages around forest areas throughout Indonesia was 25,800 and was populated by about 30 million people. In general, the community's life around the forest was very dependent on the existence of forest resources. However, in the New Order era, their access to forest resources was still limited (Yuwono and Wiyono, 2008; Awang, 2006). The fall of the New Order regime opened up opportunities for a new reconfiguration of forest management in Indonesia with the recognition of community rights to forest resources (Tjokrowinoto, 1999). As a forester, President Jokowi had a high commitment to empower the community in forest management. In 2015 - 2019 President Jokowi's government had allocated 12.7 million hectares of forest area to be managed by villagers around the forest through the Social Forestry program (KLHK, 2019, Sudiyono, 2019; Yuwono and Novianto, 2018). The goal was to address the sharing tenure disputes within the forest area, promote community wellbeing and conserve forest functions (KLHK, 2016).

Empowering forest management communities was not an easy job. At least three stages were needed in the community empowerment process, namely: (1) Preparing conditions or climate that enable the community's potential to develop optimally (enabling); (2) Strengthening the community's knowledge capacity and ability to solve problems and fulfill their needs (empowering); (3) Protecting the interests of weak groups so that they were not oppressed by strong groups and avoiding unequal competition (protecting) (Ife and Tesoriero, 2008; Alfitri, 2011; Zubaedi, 2013; Sulistiyani, 2017; Suprapto, 2019). The process of empowering communities around forests through the Social Forestry program was not an easy task and required a long time. Thus, it was not surprising that until December 2019 the achievement of Social Forestry permits only reached 3.4 million hectares or around $2.7 \%$ of 
the target set by the government (KLHK, 2019). The process of community empowerment was deemed quite difficult if it was faced only by forestry extension agents because of limited human resources and budgetary funds. Therefore, the role of stakeholders was needed to help the community obtain a license for Social Forestry, as the DAMAR Foundation did in 2000-2007 with financial support from The Ford Foundation in assisting the Kalibiru community.

According to Arnstein, granting of a Social Forestry permit to KTHKm Mandiri was the highest form of community engagement in forest resources management if calculated by eight levels of participation (Nasdian, 2014; Mitchell, et al, 2003; Ife and Tesoriero, 2008). For 35 years, the Kalibiru people have been given the freedom to use and independently control the 29 ha protected forest area to enhance their health. Communities were given the freedom to plan and implement sustainable management of forests according to local capacity and knowledge.The community was also given the right to monitor the project and review the results of the HKm plan through group member meetings. The government's role, in this case, the DIY Forest Service and the Ministry of Environment and Forestry was only as a facilitator in the licensing process, human resource development, management plan endorsement, five-year program implementation evaluation.

Strong internal democratic control of farmers' communities was needed to ensure their progress with such huge community rights and authority in the Social Forestry project (Baynes, et al., 2015). KTHKm Mandiri already had quite strong internal institutional governance which was reflected in (1) the existence of strong group leaders; (2) the existence of clear internal group rules; (3) the results of group undertaking were distributed fairly and transparently. Strong leadership was evidenced by Mr Sisparjan's, as the head of KTHKm Mandiri, ability to support and work together to develop Kalibiru Nature Tourism in moving members and group administrators. The head of KTHKm Mandiri also had strong stakeholder networking. This was proved by frequent invitations for the Head of KTHKm to attend and became speaker in various events related to the Social Forestry program at the local and national level. KTHKm Mandiri already had internal regulations in the Articles of Association, Bylaws, and group meeting decisions. KTHKm Mandiri also had a process and guidelines to share the results of group business as laid out in the KTHKm Mandiri Bylaws document.

KTHKm Mandiri utilized protected forest areas without having to cut down trees. KTHKm Mandiri only used non-timber forest products, in the form of fruits, empon-empon, crops and forage for animal feed, and forest environmental services. The forest utilization model conducted by KTHKm Mandiri followed the concepts of resources-based management and ecosystembased management (Fandeli, 2014; Simon, 2008; 2010). Even for the operation of Kalibiru Nature Tourism, it had led to the implementation of the landscape-based management concept, because it had integrated the utilization of forest areas and non-forest areas in the vicinity (Fandeli 2014). The natural beauty of Kalibiru offered by KTHKm Mandiri was not only limited to protected forest areas but also other areas in the vicinity. The forest management model of KTHKm Mandiri was far more advanced than forest concession (HPH) and industrial plant (HTI) firms outside Java. HPH and HTI concessions continued to apply conventional forest management models in the context of forestry-based management, which was oriented primarily to the wood extraction from natural forests and timber harvesting from forests plantations.

KTHKm Mandiri had applied the community-based ecotourism concept in managing Kalibiru Nature Tourism, namely the exploitation of nature tourism oriented on the active community participation, as well as institutions and local wisdom in the natural resources management to enhance community welfare while preserving the environment. KTHKm Mandiri was considered successful in implementing the community-based ecotourism concept, because it had been able to provide economic benefits to the community, whereas stocked forest was sustainable and the function of protected forests as controlling ecosystems was maintained. The success of KTHKm Mandiri in Kalibiru Nature Tourism business was demonstrated by the number of visitors and revenue that continued to rise from 2010 through 2017. Kalibiru Nature Tourism's number of visitors reached its peak in 2016, comprising 443,070 tourists. Meanwhile, the revenue generated from Kalibiru Nature Tourism services peaked at 5.4 billion rupiah in 2017.

The successful exploitation of Kalibiru Nature Tourism had given economic and social impacts to the members of KTHKm Mandiri, the 
Kalibiru Village community, and other surrounding communities. The economic benefits forms of the existence of Kalibiru Nature Tourism included (1) Profit sharing for members of $10 \%$ and pioneers of $7.5 \%$ KTHKm Mandiri as presented in Table 4; (2) Job opportunities and new businesses possibilities for KTHKm Mandiri members and the Kalibiru Village community as presented in Table 5; (3) Social assistance for the poor and orphans of Kalibiru Village communities by $5 \%$ as shown in Table 4 . The economic benefits indicated that the implementation of the Social Forestry program in KTHKm Mandiri was in line with the objectives set by the government, namely increasing community welfare around the forest area.

The Social Forestry Program through the exploitation of Kalibiru Nature Tourism by KTHKm Mandiri had also encouraged social change for Kalibiru people and surrounding areas. These social changes comprised two dimensions, namely: (1) Changes in orientation at the individual farmer level; (2) Changes at the farmer group level. Changes in orientation at the individual farmer level included: (1) Changes from loggers and forest loggers to forest managers and guards; (2) Changes from forest harvester and cultivators to employees service providers, and business owners; (3) Changes from farmers works and acts individually to farmer groups' member who work and act together with the group; (4) Changes from farmers who manage and use subsistent forest products to commercialize. According to Himes and Moore, social changes took place in the Kalibiru village community were included in the context of social changes in the structural aspect (Martono, 2014), including changes happened in the organization of work and the community's position in forest management.

Meanwhile, changes in orientation at the level of farmer groups (1) Changes from the role of farmer group leaders to eco-socio entrepreneurs; (2) Changes from managing parttime farmer groups to becoming professionals; (3) Changes from the use of forests to meet individual needs to meet the needs of members, groups and communities; (4) Changes from no specific allocation of forest business results to help the poor; (5) Changes from forest management practices that only related to the forestry and agriculture technical activities to align with infrastructural and rural socioeconomics development

\section{Conclusions}

In Indonesia, there has been a shift in forest management strategies from state-based forest management to community-based forest management. This shift in forest management strategy was realized in the form of the Social Forestry program. One example of a successful Social Forestry program implementation is the management of protected forest areas through the exploitation of Kalibiru Nature Tourism KTHKm Mandiri located in Kulon Progo Regency. The forms of community empowerment strategies in protected forest management carried out by KTHKm Mandiri, namely (1) Institutional management strategies through strong institutional governance of farmer groups; (2) Forest area management strategies through the application of resources-based management concepts, ecosystem-based management, and landscape-based management; and (3) Forest management business strategy through the application of community-based ecotourism concept.

Community empowerment through the exploitation of Kalibiru Nature Tourism has been proven to provide economic benefits to group members, as well as the Kalibiru and surrounding communities, in the form of (1) profit sharing; (2) employment; (3) new business opportunities; and (4) social funding assistance. In addition, the existence of Kalibiru Nature Tourism has also led to social changes in the community of Kalibiru Hamlet and its surroundings. These social changes include two dimensions, namely: (1) changes in orientation at the individual farmer level; and (2) orientation changes at the farmer group level.

\section{Acknowledgments}

Our best gratitude addresses to Universitas Gadjah Mada (UGM) for funding this research. We also thank the students who helped during the data collection process in the field. We also do not forget to express our highest gratitude and appreciation to the KTHKm Mandiri management who were willing to be the resource persons in this research.

\section{References}

Alfitri, 2011. Community Development, Teori dan Aplikasi. Yogyakarta: Pustaka Pelajar. 
Awang, S.A., 2006. Sosiologi Pengetahuan Deforestasi: Konstruksi Sosial dan Perlawanan. Yogyakata: Debut Press.

Baynes, J., Herbohn, J., Smith, C., Fisher, R., Bray, D., 2015. Key factors which influence the success of community forestry in developing countries. Global Environmental Change 32 (2015) 226-238. http://dx.doi.org/10.1016/j.gloenvcha.2015 .09

Fahmi, A., A. Susanti, H. Marhaento, I. Bakhtiar, M.A. Imron, R. Sanyoto. 2018. Kehutanan Milenial: Tantangan Kehutanan Indonesia di Era 4.0. Yogyakarta: Fakultas Kehutanan.

Fandeli, C. 2014. Bisnis Konservasi, Pendekatan Baru dalam Pengelolaan Sumberdaya Alam dan Lingkungan Hidup. Yogyakarta: Gadjah Mada University Press.

Fandeli, C. dan Mukhlison, Eds. 2000. Pengusahaan Ekowisata. Yogyakarta: Fakultas Kehutanan Universitas Gadjah Mada.

Ife, J. dan Tesoriero, F., 2008. Community Development, Alternatif Pengembangan Masyarakat di Era Globalisasi. Yogyakarta: Pustaka Pelajar.

Kementerian Lingkungan Hidup dan Kehutanan - KLHK. 2016. Peraturan Menteri Lingkungan Hidup dan Kehutanan No. P.83/MENLHK/SETJEN/KUM.1/10/2016 tentang Perhutanan Sosial.

Kementerian Lingkungan Hidup dan Kehutanan - KLHK. 2018. Refeksi Hutan Sosial KLHK 2018: Hutan Untuk Rakyat. Siaran Pers PPID Kementerian Lingkungan Hidup dan Kehutanan. http://ppid.menlhk.go.id/siaran_pers/brows e/1718. Diakses tanggal 14 Oktober 2019.

Kementerian Lingkungan Hidup dan Kehutanan - KLHK. 2019. Ruang Informasi Publik Perhutanan Sosial. http://pkps.menlhk.go.id. Diakses tanggal 14 Oktober 2019.

Martono, N. 2014. Sosiologi Perubahan Sosial: Perspektif Klasik, Modern, Postmodern, dan Postkolonial. Jakarta: PT Raja Grafindo Persada.
Mitchell, B., Setiawan, B., Rahmi, D.H., 2003. Pengelolaan Sumberdaya dan Lingkungan. Yogyakarta: Gadjah Mada University Press.

Nasdian, F.T., 2014. Pengembangan Masyarakat. Jakarta: Yayasan Pustaka Obor Indonesia.

Nugroho, I. 2011. Ekowisata dan Pembangunan Berkelanjutan. Yogyakarta: Pustaka Pelajar.

Simon, H. 2008. Pengelolaan Hutan Bersama Masyarakat (Cooperative Forest Management): Teori dan Aplikasi pada Hutan Jati di Jawa. Yogyakarta: Pustaka Pelajar.

Simon, H. 2010. Perencanaan Pembangunan Sumberdaya Hutan: Jilid 1A Timber Management. Yogyakarta: Pustaka Pelajar.

Sudiyono. 2019. Ketahanan Sosial dan Perhutanan Sosial: Kalibiru-Kulon PogoYogyakarta. Dalam Hidayat, H. (Ed.), Deforestasi dan Ketahanan Sosial. Jakarta: Yayasan Pustaka Obor. Halaman 105 162.

Suhardjito, dkk., 2000. Pengelolaan Hutan Berbasis Masyarakat. Yogyakarta: Pustaka Kehutanan Masyarakat FKKM. Halaman: 8-12.

Sulistiyani, A.T., 2017. Kemitraan dan ModelModel Pemberdayaan. Yogyakarta: Penerbit Grava Media.

Suprapto, T., 2019. Pemberdayaan Masyarakat Informasi, Konsep dan Aplikasi. Yogyakarta: Pustaka Pelajar.

Tjokrowinoto, M., 1999. Desentralisasi Pengelolaan Sumberdaya Hutan, Politik Pemberdayaan Daerah, dan Integrasi Nasional. Dalam: Awang, S.A., Ed. Forest for People Berbasis Ekosistem. Pustaka Hutan Rakyat. Yogyakarta: Bayu Indra Grafika. Halaman: 156-160.

Vitasurya, V.R. 2016. Local Wisdom for Sustainable Development of Rural Tourism, Case on Kalibiru and Lopati Village, Province of Daerah Istimewa Yogyakarta. Procedia - Social and Behavioral Science, Volume 216, 6 January 2016, Pages $97-108$. https://doi.org/10.1016/j.sbspro.2015.12.01 $\underline{4}$. 
WWF Indonesia. 2009. Prinsip dan Kriteria Ekowisata Berbasis Masyarakat. Jakarta: Direktorat Produk Pariwisata, Direktorat Jenderal Pengembangan Destinasi Pariwisata, Departemen Kebbudayaan dan Pariwisata dan WWF-Indonesia. http://awsassets.wwf.or.id/downloads/wwf indonesia_prinsip_dan_kriteria_ecotouris m_jan_2009.pdf

Yuwono, T., dan Novianto, E. 2019. Belajar dari Tapak Perhutanan Sosial. Yogyakarta: Java Learning Centre (JAVLEC).

Yuwono, T. dan Wiyono. 2008. Cooperative Forest Management: Potret Pengelolaan Hutan Kabupaten Ngawi Di Era Otonomi Daerah. Yogyakarta: Datamedia.

Zubaedi, 2013. Pengembangan Masyarakat, Wacana dan Praktik. Jakarta: Kencana. 